\title{
Vegetation Cover Changes in Ngorongoro Conservation Area from 1975 to 2000: The Importance of Remote Sensing Images
}

\author{
Elliott P. Niboye*
}

Institute of Development Studies, University of Dar es Salaam, P.O. Box 35169, Dar es Salaam, Tanzania

\begin{abstract}
Ngorongoro conservation area is a multiple land-use system established in 1959 to provide for both wildlife conservation and economic development of resident Maasai pastoralists. A study was conducted by analyzing remote sensing images (Landsat MSS 1975, Landsat TM 1991, and Landsat TM 2000) in order to determine trends in vegetation cover changes between 1975 and 2000. The results indicates that major changes in the study area from 1970 to 2000 involved increase in woody vegetation cover types including forest $(+48.7 \%)$, bush land $(+42.7 \%)$; and loss of scrubland $(-29.1 \%)$ and grasslands $(-37.0 \%)$. Other changes involved invasion of highland grassland by unpalatable grass species $(-34.4 \%)$. The period covered was associated with restrictive conservation policies that disrupted traditional pastoral mobility restricting large herds of livestock on highland areas that induced range deterioration. It is concluded that pastoral land use system has preserved the savanna landscape in Ngorongoro area whereas land-use policies that disrupts traditional pastoral land use systems threaten a breakdown of savanna ecosystem that supports a tourism industry in the area.
\end{abstract}

Keywords: Ngorongoro conservation area, conservation policies, non-equilibrium models, vegetation cover change, pastoral systems, landsat imagery, Tanzania.

\section{INTRODUCTION}

\subsection{Background Information}

Ngorongoro Conservation Area (NCA) is a multiple land-use system, which combines both human economic development and wildlife conservation. The area was gazetted in 1959, thus has attained more than 48 years experience of combining both conservation and economic development. It is a unique conservation unit and serves as model of multiple land-use systems in the Sub Saharan Africa. The principal land uses allowed in the area include conservation of natural resources, extensive livestock production, agro-pastoralism, small scale cultivation and tourism. It is this experience with multiple land-use philosophy as well as the areas' special conservation values and attributes that have made the NCA a focal point of international interests [1].

\subsection{Location and Conservation Value}

The NCA is located in Northern Tanzania $\left(34^{0} 52^{\prime}-35^{0}\right.$ $58^{\prime}$ E, $2^{0} 30^{\prime}-3^{0} 38^{\prime} \mathrm{S}$ ) and covers $8,283 \mathrm{~km}^{2}$. It borders Loliondo Game Controlled Area (LGCA) to the North, Serengeti National park to the west, Lake Eyasi to the south and agricultural communities on south eastern border (Fig. 1). Ecologically the area is very diverse and can be categorized into five zones: the Crater highlands, Salei plains, Gol Mountains, Serengeti plains, and Kakesio/Eyasi escarpment. The rainfall is seasonal and highly variable ranging from 400 to $600 \mathrm{~mm}$ in lowland plains to more than $1200 \mathrm{~mm}$ p.a. in highland areas [2]. The vegetation in the area is equally

*Address correspondence to this author at the Institute of Development Studies, University of Dar es Salaam, P.O. Box 35169, Dar-es-Salaam, Tanzania; Tel: +255 22 2410075; E-mail: epniboye@udsm.ac.tz complex consisting of montane forest and tussock grassland in the highlands to semi-arid woodlands and short grasslands in the escarpment and plains $[3,4]$.

Furthermore, the NCA is part of the Serengeti ecosystem, a home of largest concentration of game animals than any place on Earth.

The area is the main wet season grazing area for the majority of Serengeti migratory herds numbering approximately $1.5 \mathrm{mil}$ wildebeest; 450,000 gazelles and 260,000 zebras [5]. It is also rich in archaeological sites with evidence of evolution of mankind. In addition, the NCA has been the traditional homeland of the Maasai ethnic group for nearly three centuries, and it is also a refuge for pastoralists from other areas during times of drought $[6,7]$. The NCA, therefore, plays a crucial role in supporting the pastoral land use system of Ngorongoro District. Due to these values, the NCA was inscribed on the World Heritage Sites list in 1979 and recognised as International Biosphere Reserve under UNESCO's Man and Biospheres Programme in 1982 [8]. Its features also attract many visitors that make the area to be one of the most visited tourist destinations in Tanzania. Thus, the multiple land use policies and practices in NCA have predated the co-management and community based natural resource management paradigms. This study, applying land cover change analysis, attempts to establish the impact on the NCA ecosystem of the restrictive conservation policies that disrupted traditional pastoral mobility in the Ngorongoro ecosystem thus confining large herds of livestock only in highland areas.

\subsection{Evolution of Conservation Policy and Management Plans in NCA}

From its establishing legislature the Ngorongoro Conservation Ordinance No. 14 of 1959, NCA was premised 


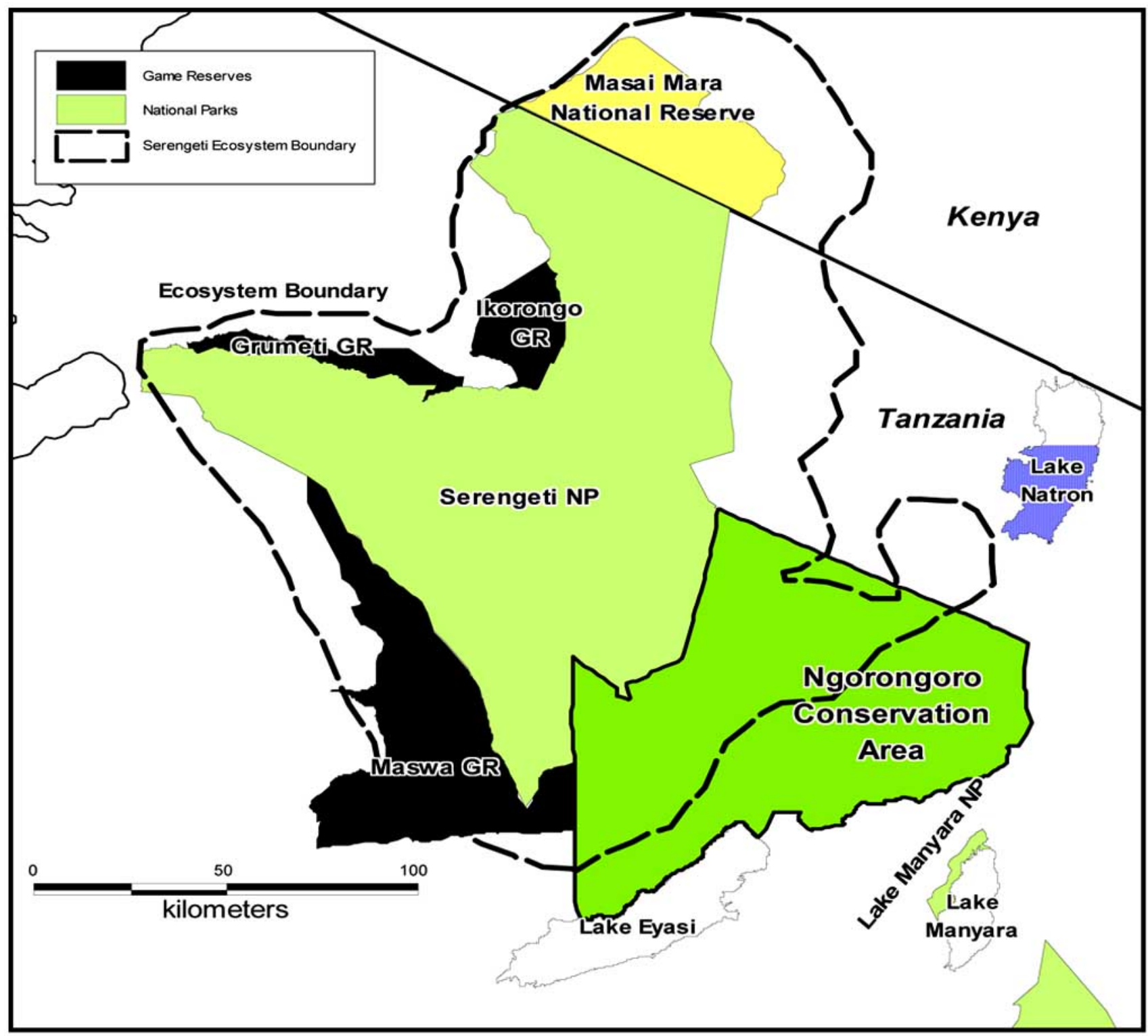

Fig. (1). Ngorongoro conservation area in relation to serengeti ecosystem.

on European model of a protected landscape, in which human habitation and activities have been permitted throughout an entire area. However, from its inception the multiple land use approach has been contested between conservationists and social welfare lobbies. For these reasons, the NCA has been subjected to different jurisdictions and a number of policy and legislative changes implemented by state governments in attempts to attain a compromise between competing lobbies.

The history of wildlife conservation in the SerengetiNgorongoro ecosystem dates back to 1929, when the German colonial government established a game reserve in central Serengeti. This was followed in 1951 by formation of the Serengeti National Park that included present day Serengeti National Park and the Ngorongoro high lands. At that time both cultivation and pastoralism were allowed in the National Park. However, the conservationist lobby of the west was opposed to the idea of carrying out economic development activities in the conservation area in tandem with wildlife protection. The conservationists' assumption was that human activities are detrimental to wildlife conservation and therefore they advocated for total preservation of wildlife habitat and the exclusion of human activities from the National Park. The same assumptions have since been influencing the governments' conservation policies. For instance, acting on said conservationists pressure, in 1954, the government prohibited agricultural activities to be carried out in the whole Park area. This decision by the government was met by a strong reaction from both pastoralists and cultivators in the area. The resistance prompted the British colonial government to appoint a Committee of Enquiry in 1956, which proposed partitioning the Park into two separate units. The present day Serengeti National Park in the west was devoted exclusively to wildlife conservation and tourism, while the Ngorongoro 
Conservation Area in the east was to combine both wildlife conservation and economic development of Maasai pastoralists.

The NCA was established by the Ngorongoro Conservation Ordinance of 1959, which was later modified by the Game Park Laws (Amendment) Act No. 14 of 1975. Since its inception, the NCA has demonstrated two distinct approaches to multiple land-use management in the area. From 1959 to approximately 1975, the NCA allowed the wildlife conservation and human habitation throughout the conservation area. However, starting from 1975, the Ngorongoro Conservation Area was divided into zones as proposed in 1968 management plan. The zoning specified that the Ngorongoro Crater areas and Northern Highland Forest Reserve be accorded a higher degree of conservation status. Therefore human habitation in the Ngorongoro Crater was prohibited and this coincided with restrictions on land resource use in the wider NCA, with a total ban on cultivation. Since 1975, the NCA has been managed as a buffer zone to both the Ngorongoro Crater and adjacent Serengeti National Park [9]. The implementation of restrictive conservation policies mentioned above disrupted the traditional pastoral grazing system of the Maasai tribal group leading to resource-use conflicts between local Maasai communities and the conservation authorities $[10,11]$.

The above cited resource use conflict threatened the coexistence between wildlife and pastoralism as well as sustainability of the NCA landscape. A number of actions were taken to resolve this problem. A BRALUP (Bureau of Resource Assessment and Land-use Planning of the University of Dar es Salaam, now defunct) plan was drafted in 1982, recommending local participation in management of the NCA and creating tenure security through village system. Nevertheless, this never took place. The ad hoc Ministerial Committee Report of 1992, emphasized that sustainable multiple land-use could be achieved by balancing human needs and conservation of wildlife. The report recommendations were adopted as the NCA policy (the NCA Charter) and provided basis for formulation a ten-years general management plan, which was developed through involvement of local communities, and it was adopted in 1996 [12].

When commenting on this development, MacCabe et al. [13] observed that this was a step in the right direction. However, the most sensitive issues that underlie resource-use conflicts in the area like zoning, tenure security and village boundaries were never addressed comprehensively in the plan.

Furthermore, decisions on conservation policies in the NCA tend to employ a precautionary approach, as the likely impacts of policy changes are not well known and long term studies to establish the ecological trends are very limited. Moreover most human induced changes in conservation areas are not readily reversible [13].

\section{METHODOLOGY}

Remote sensing and Geographic Information System (GIS) techniques, field survey, Participatory Rural Appraisal approaches (specifically transect walks, village resource mapping, village trend lines data and focused group discussions were used) and documentary search were employed to collect primary and secondary data. Two study villages were randomly selected from three main zones: highlands, midlands and lowland areas. In each study village transect walks $(2 \mathrm{~km})$ and PRA data collection methods were applies to obtain data on land uses, vegetation cover changes and livestock grazing cycles.

\subsection{Primary Data Collection}

\subsubsection{Land-Cover Types Determination}

A combination of GIS techniques and field verification by ground-truthing, were used to determine land-use and land cover types in the areas. Data sources for GIS processing included the aerial photographs (of early 1960s), NCA topographic map sheets at a scale of 1:50000 (UTM zone 36 south); 3 remote sensing images: Landsat MSS scene of $17^{\text {th }}$ July 1975 , Landsat TM scene of $27^{\text {th }}$ July, 1991 , Landsat TM scene of $20^{\text {th }}$ July of 2000 for path/row 169/62. Map features and delineated vegetation classes were digitised using ERDAS Imagine, ArcInfo and ArcView software packages. Combinations of supervised and visual methods were employed during classification of vegetation classes. The vegetation classes were verified by groundtruthing surveys in the study villages. The local communities provided timeline data, which together with geo-referencing using GPS supplemented information obtained from remote sensing imageries. The geo-referenced land cover maps for the study area were produced using ArcView software. Change detection matrix tables were developed and used for quantification of land cover changes. Assessment of major land cover classes and the detection of changes associated with these classes were carried out through a number of steps shown in the methodology flow chart illustrated in Fig. (2).

\section{(i) Pre-processing of the Satellite Images}

\section{(a) Creation of Sub-Scenes}

Three sub-scenes of the same size from the Landsat MSS (1975) and from Landsat TM images (1991 and 2000) -of the study area - were extracted from the full satellite scenes.

\section{(b) Image Rectification}

The available satellite images had already been corrected for radiometric distortions. The developed sub-scenes were only subjected to geometric correction to allow for compensation for various errors introduced by several factors including: curvature of the earth, earth rotation effects, atmospheric refractions, relief displacement, variation in platform altitude, panoramic distortions (wide field of view of some sensors), altitude and velocity and panoramic effects related to the imaging geometry.

\section{(ii) Image Enhancement}

The image enhancement techniques applied in this study include: Tasseled Cap transformation to the brightness, greenness and wetness axes; the Normalized Difference Vegetation Index (NDVI) calculations and colour Density Slicing. The Tasseled Cap transformation [14] enables to optimize data viewing for vegetation studies. The operation rotates the image data structure such that the majority of information is contained in three components or features directly related to the vegetation information content. The features include: 


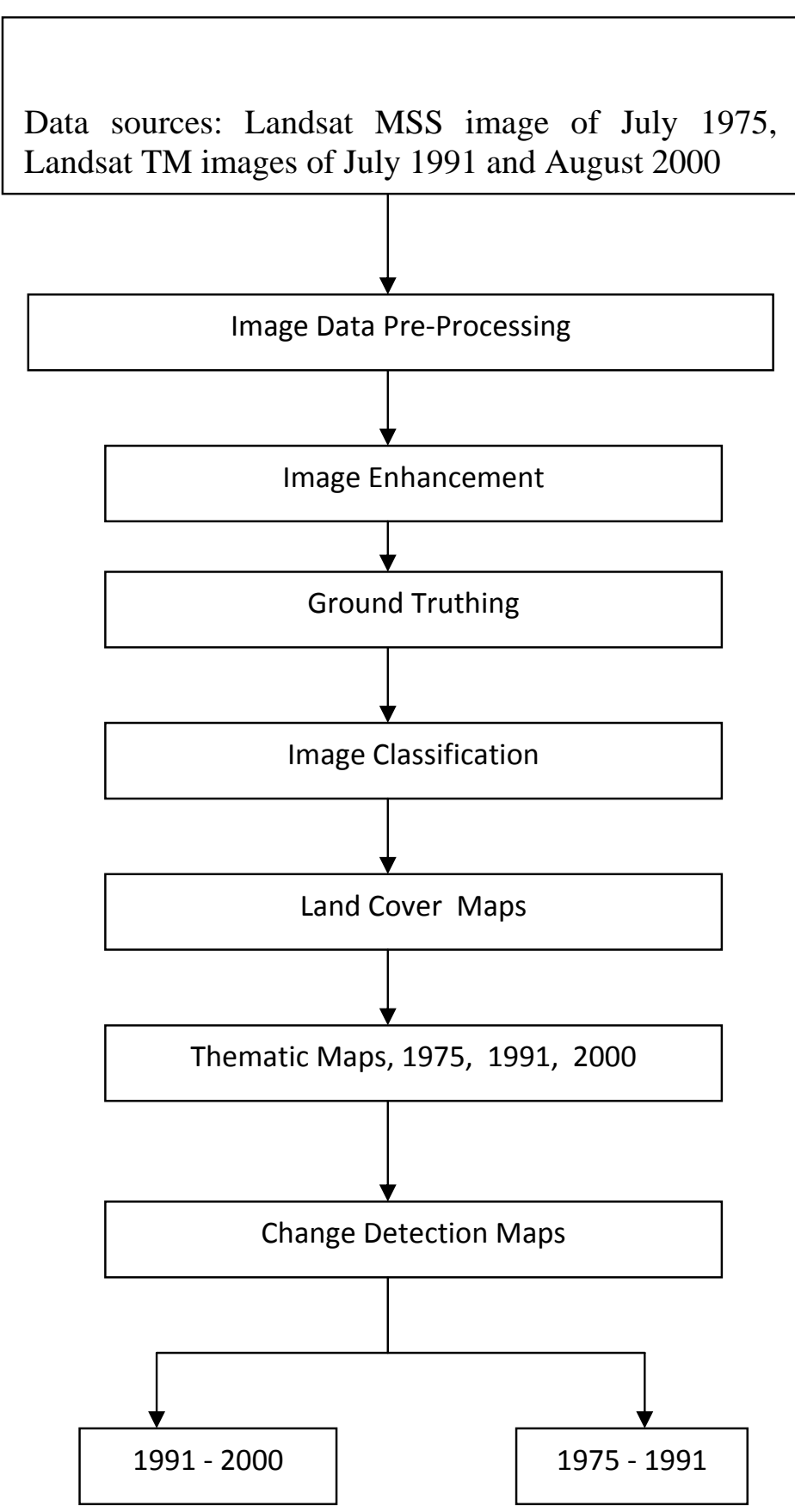

Fig. (2). Change detection flow chart.

- $\quad$ Brightness: the weighted sum of all bands defined in the direction of the principal variation in soil reflectance

- Greenness: is approximately orthogonal to brightness and is a contrast between near-infrared and visible bands. Greenness is roughly related to the amount of green vegetation in the scene

- Wetness: is related to canopy and soil moisture.

(iii) Interpretation of Satellite Images

(a) Colour Composition for Visual Interpretation

A number of band combinations were tried on the seven bands of the TM image. Subsequently the colour composition from Landsat TM bands 4,5 and 3 combinations proved to produce the best image for visual interpretation of physical and vegetation features. A number of sub-scenes for the Landsat TM developed as training areas were enhanced and printed for use in ground truthing.

\section{(b) Collection of Ground Truthing Information}

Ground- truthing was conducted in October 2002 and was based on Landsat TM image of 2000. The enhanced colour composite image printouts were used for training purposes in the field. At each of the survey sites (in five study villages), the recognizable features on both the ground and the colour composite print out were marked on the colour composite printout. The identification of features was 
Table 1. Land Covers Classes and Related Colour Composite for NCA

\begin{tabular}{|ll|l|}
\hline \multicolumn{2}{|c|}{ Land Cover/Use Type } & \\
\hline \hline 1. & Closed forest & Deep red, speckled \\
\hline 2. & Woodland & Bright red, smooth (dense woodland, montane health) as speckled (open woodland) \\
\hline 3. & Bush land & Pink, smooth (dense bushland), bright pink (scrubland) speckled (open bushland), smooth red (Highland grassland) \\
\hline 4. & Grassland: & Blue-green plus red or pink speckles (open shrubland) \\
\hline 5. & Intensive cultivation & Pale cream or reddish \\
\hline 6. & Riverine vegetation: & Bright red \\
\hline 7. & Water features (lakes, dams): & Black \\
\hline 8. & Settlements & Grey/mauve \\
\hline 9. & Road network & Greyish crooked lines network. \\
\hline
\end{tabular}

done through first locating easily-observable features such as roads, river networks and water bodies, thereafter were related to other features such as vegetation types. The features were geo-referenced using GPS. The local community members provided the onsite local knowledge including administrative locations, type of present land cover and use, and land cover changes.

Despite the small changes in land cover/use that have taken place over three years, several land cover details on the enhanced colour composite print outs for the Landsat TM images of July 2000; were identified in the field (on June, 2003). The following land cover classes were identified in the study area; with the corresponding characteristics on the 4-5-3 colour composite print-out (Table 1).

Some of the details which were obtained on the Landsat TM image with a spatial resolution of 30×30 m were lost or reduced on the Landsat MSS image with a spatial resolution of $79 \times 79 \mathrm{~m}$. Hence, by taking into consideration these factors, the land cover classes were generalized into 4 main categories that were retained for classification as follows:

1. Bare land: including areas with no active vegetation. They have the lowest NDVI values (ranging from-1 to approximately- 0.27 for the MSS image and between-0.69 to approximately- 0.40 for the TM image). This class include bare soil (recently cultivated areas, overgrazed areas, rocky area etc) and water bodies.

2. Grassland/cropland: comprising sites with very low active vegetation, thus with (lower) NDVI values (ranging from about-0.26 to approximately-10.01 for the MSS image and from about- 0.39 to approximately 0.25 for the TM image). This class comprises mainly of grasslands, farmlands and shrub grasslands.

3. Woodland: this has high active vegetation and relatively high NDVI values varying from about 0.02 to approximately 0.25 for the MSS image and from about 0.26 to approximately 0.50 for the TM image. The class includes the woodlands, thickets and bushlands.

4. Closed forest class has the highest active vegetation, thus the highest NDVI values (ranging from about 0.26 to approximately 0.54 for the MSS image and from about 0.51 to approximately 0.65 for the TM image). The class comprise of closed woodlands and montane forests.

(iv) Image Classification

The study combined both visual and digital image classifications. The digital image classification mainly based on the grey scale ranges of the calculated NDVI, used to establish main vegetation cover units. Level slicing method [15] was used for digital image classification. The slices which are intervals of series of brightness value corresponding to the ranges of NDVI values, these were established basing on the grey scale images and on training printouts.

The NDVI is by far the most commonly used in vegetation. NDVI is the difference in the near-infrared and chlorophyll reflectance divided by the sum of these reflectances. It increases with stand biomass and leaf area index [16]. The NDVI is calculated by the formula:

$\mathrm{NDVI}=\underline{\mathrm{NIR}-\mathrm{R}}$

$$
\mathrm{NIR}+\mathrm{R}
$$

Whereby:

\section{NDVI is the Normalised Difference Vegetation Index}

- $\quad$ NIR is the Near-infrared Band which is band 7 for Landsat MSS, band 4 for Landsat TM,

- $\quad \mathrm{R}$ is the Red Band, which is band 5 for Landsat MSS, band 3 for Landsat TM,

According to ERDAS [17], the NDVI ranges from - to +1 , but these extreme values may not be found on a given image.

A combination of supervised classification and visual classification was used to classify the land cover types in the study area. Map features and delineated vegetation classes were digitised using ArcView software to produce the georeferenced topographic maps for 1975, 1991 and 2001 of the study area. Change detection analysis was conducted by using overlays generated from GIS land cover/use maps plus local perception information. Change detection matrix tables were produced to quantify land cover changes and produce the land cover change maps for two time series 1975 to 1991 , and 1991 to 2000 . 


\subsection{Secondary Data Collection}

Secondary data were collected through search of documented reports, research studies, government policies and NCA management plans.

\section{RESULTS AND DISCUSSION}

\subsection{Main Land Cover/Use Types in Ngorongoro Conservation Area}

Ngorongoro Conservation Area (NCA) is ecologically diverse as described in the preceding pages. A comprehensive vegetation cover types of NCA was first described by Herlocker and Dirschl [18], who delineated eight cover types:

(1) Montane health,

(2) Bamboo forest,

(3) Evergreen forest,

(4) High woodlands,

(5) Low woodlands,

(6) Medium grasslands,

(7) Short grasslands, and

(8) Sand dunes grasslands.

A landcover classification system used in this study to describe vegetation cover types of Ngorongoro Conservation Area was adopted from Herlocker and Dirschl [18] and Pratt and Gwyne [19] description of East Africa vegetation.

The distribution of main land cover types of NCA is shown in Table 2 and Figs. (3-5). The data show that the main land cover type in Ngorongoro area is grassland which accounted up to $56.0 \%, 35.2 \%$, and $35.3 \%$ of the total area in 1975, 1991, and 2000, respectively. The grassland here refers to short and medium grass plains found in lowland and mid altitude areas. Highland grasslands are dominated by tall tussock grass species restricted to the highland areas. They form a distinct vegetation cover type on the remote sensing imagery, comprising $4.3 \%$ of the area.

Table 3 shows net area cover changes from 1975 to 1991 and from 1991 to 2000, using 1975 as base year. The results show that in the overall there was a substantial increase in woodlands $(11.9 \%)$, forests $(52.4 \%)$, bush land $(42.7 \%)$, and highland grass land (34.7\%). Whereas the cultivated area increased by 1.3 fold. During this period there was a net loss of grass lands $(-37.1 \%)$ and scrubland $(-29.1 \%)$.

However, only slight cover change took place between 1991 and 2000, although different patterns of cover changes occurred during the two time intervals. Both forests and woodland increased between 1975 and 1991 but they decreased as from 1991 to 2000 . On the other hand, loss of lowland grasslands and encroachment on highland grassland increased over the two periods under consideration.

The vegetation cover changes indicate the retrogressive vegetation changes that could be partly associated with the different conservation policies pursued in the NCA. As from 1975 to 1991 restrictive policies that prohibited access and economic activities from most of areas in the NCA were implemented. A policy change was carried out in 1992 when a ban on cultivation in the NCA was partially lifted, and so as to implement benefit sharing policy and ensure local participation, a controlled access to restricted grazing areas was instituted. This decrease in grassland area might be attributed to conversion of grasslands into other woody vegetation formation.

The increase in woodlands and forests could be attributed to implementation of conservation policies of Ngorongoro Conservation Area Authority (NCAA), as well as by the introduction of agro-forestry in areas bordering the Northern Highland Forest Reserve (NHFR) as alternative source of energy. The decrease in forest area during 1991 to 2000 can be due to cultivators' encroachment on the highland areas, particularly in the North East areas, where the NHFR borders farming communities in Karatu and Monduli districts. Lissu

Table 2. Land Cover Types in Ngorongoro Conservation Area for 1975, 1991, and 2000

\begin{tabular}{|c|c|c|c|c|c|c|}
\hline Forest & $93,128.6$ & 11.6 & $141,940.6$ & 17.7 & $138,437.0$ & 17.2 \\
\hline Montane heath & $24,235.4$ & 3.0 & $24,235.4$ & 3.0 & $24,235.5$ & 3.0 \\
\hline Woodland & $11,066.2$ & 1.4 & $143,417.5$ & 17.9 & $142,735.7$ & 17.8 \\
\hline Grassland & $449,875.1$ & 56.0 & $282,977.0$ & 35.2 & $283,307.1$ & 35.3 \\
\hline Highland grassland & $25,438.8$ & 3.2 & $32,453.2$ & 4.4 & $34,187.1$ & 4.3 \\
\hline Cultivated area & 108.9 & 0.01 & $16,909.1$ & 2.1 & $17,695.9$ & 2.2 \\
\hline Bare ground & 31.2 & 0.004 & 807.7 & 0.1 & $1,021.7$ & 0.13 \\
\hline Total & 802898.6 & 99.9 & 802898.4 & 100.0 & 803056.5 & 100.0 \\
\hline
\end{tabular}




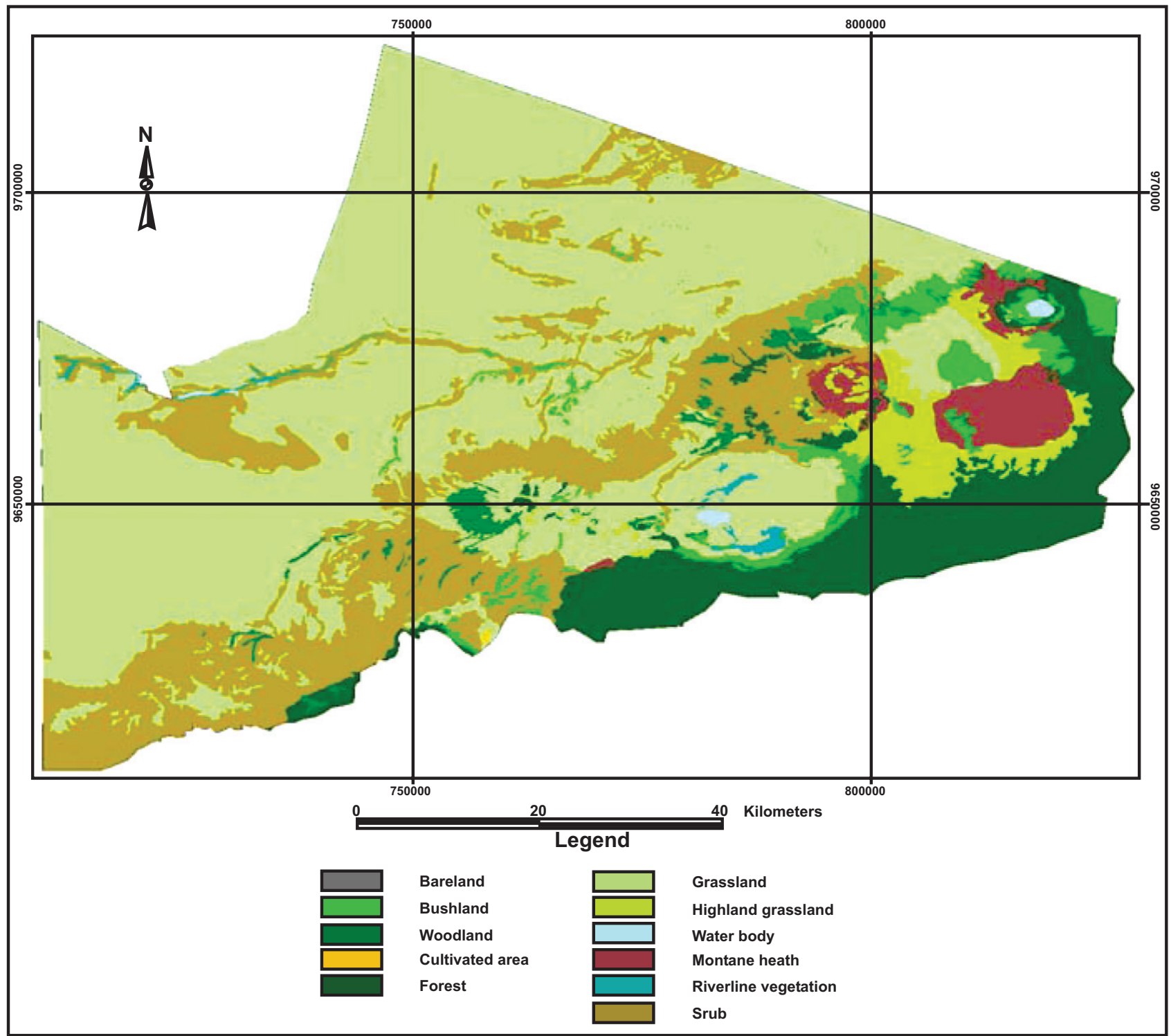

Fig. (3). Map of land cover types of NCA on January 1975.

[20] reported extensive deforestation of NHFR in the disputed Irmelili village, where the village land extends between Monduli district and Ngorongoro Conservation Area, while the village government is under Monduli district council. During the period under discussion, the highland grasslands increased by $+34.4 \%$. This includes an increase of $+27.6 \%$ that occurred between 1975 and 1991 followed by a $+6.8 \%$ percent increase from 1991 to 2000 . This increase can be attributed to a progressive invasion of highland areas by an invasive grass species Eleusine jaegeria ('manyatta' grass).

According to Makacha and Frame [21], Eleusine jaegeria is unpalatable grass species with relatively low nutritive value to cattle and wildlife. Therefore, an increase in this species is an indication of retrogressive process taking place in NCA highlands. Although the area under cultivation is relatively small in size, it experienced substantial increase between 1975 and 1991 (of 56.02\%) followed by further increase (of $72.0 \%$ ) starting from 1991 to 2000. The earlier increase occurred notwithstanding a ban imposed between 1975 and 1992. This implies that cultivation has become an integral part of household livelihood coping strategies among NCA Maasai, which is undertaken in order to improve household food security. The observed increase in cultivation between 1991 and 2000 is related to a partial lift on a ban to cultivate when garden farming of 0.5 ha per housewife and her children was allowed. The results further refute claims by some NCA officials that high influx of immigrants in the area is the main cause of expansion of cultivation. 


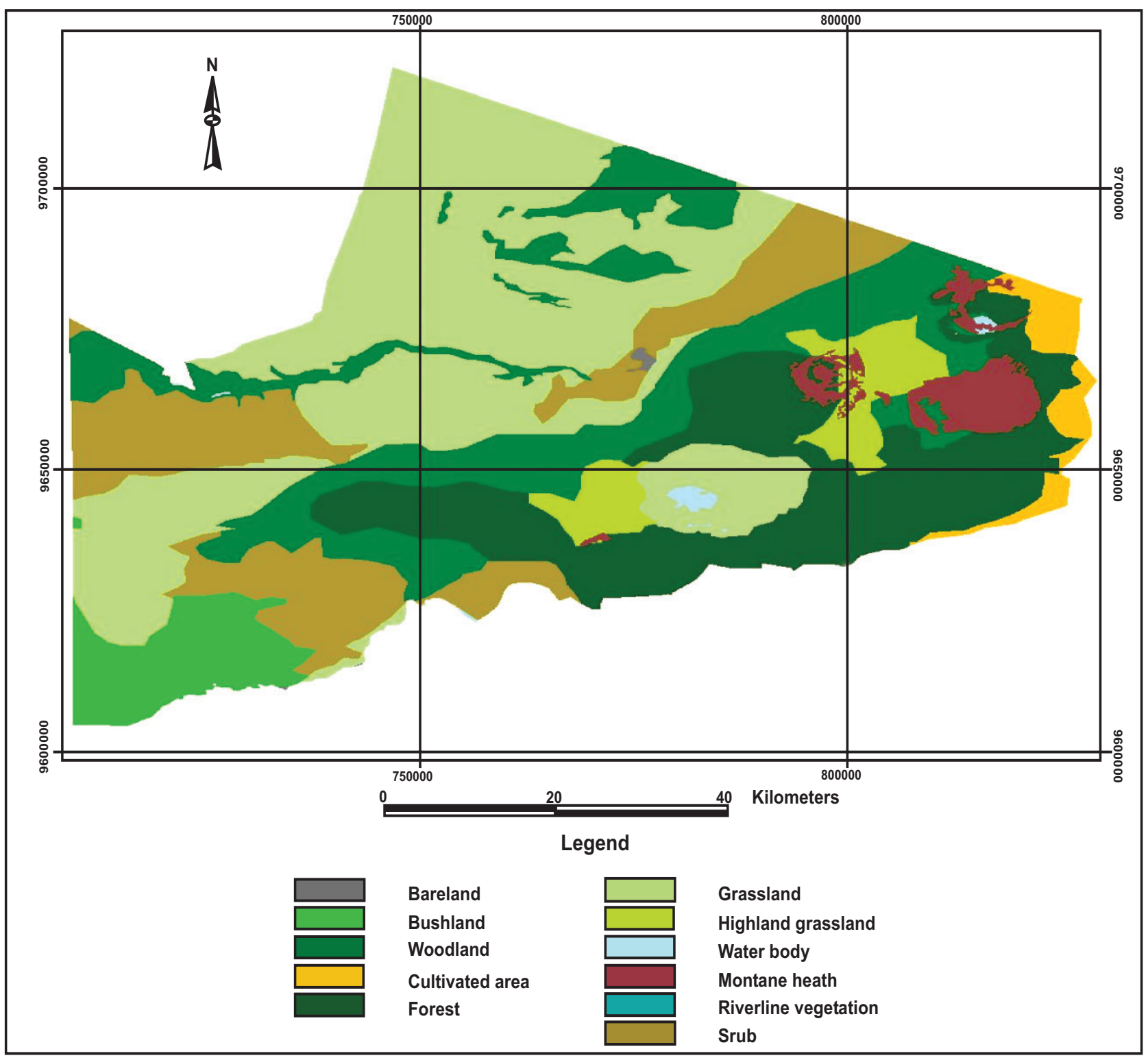

Fig. (4). Map of land cover types NCA on January 1991.

\subsection{Land Cover Change Detection Matrix for 1975 to 1991 and 1991 to 2000 in Ngorongoro Conservation Area}

The land cover detection matrix was used to determine the actual direction of land cover changes. Tables $\mathbf{4}$ and $\mathbf{5}$ and Fig. (6) show the direction of change and net vegetation cover changes in terms of absolute area and percentages. Table 4 suggests that most changes involved conversion of grasslands into scrubland (18.87\%), and change of scrubland to woodland $(5.72 \%)$. Encroachment of highland grassland decreased by $2.1 \%$. Other changes involved encroachment of forests by cultivation reducing the highland grassland by $2.3 \%$.

Encroachments mainly occurred on the north-east and north-south parts of the Northern Highland Forest Reserve which are bordering farming communities in Karatu, Mbulumbulu, and Oldeani areas. The apparent encroachment could also be attributed to unclear and disputed boundary of the forest reserve and neighbouring village land. The results further reveal a low level of conversion of grasslands to cropland. This could be attributed to customs, which prohibits illegal burning or unauthorized tilling of prime grazing areas. It is discernible from the data that most vegetation changes that occurred between 1975 to1991 were generally succession towards woody vegetation types.

Table 5 and Fig. (7) show the direction of land cover changes that occurred in NCA between 1991 and 2000. The main changes that took place involved -0.23 percent loss of forest to highland grassland; and conversion of -0.04 percent of woodland to grasslands. 


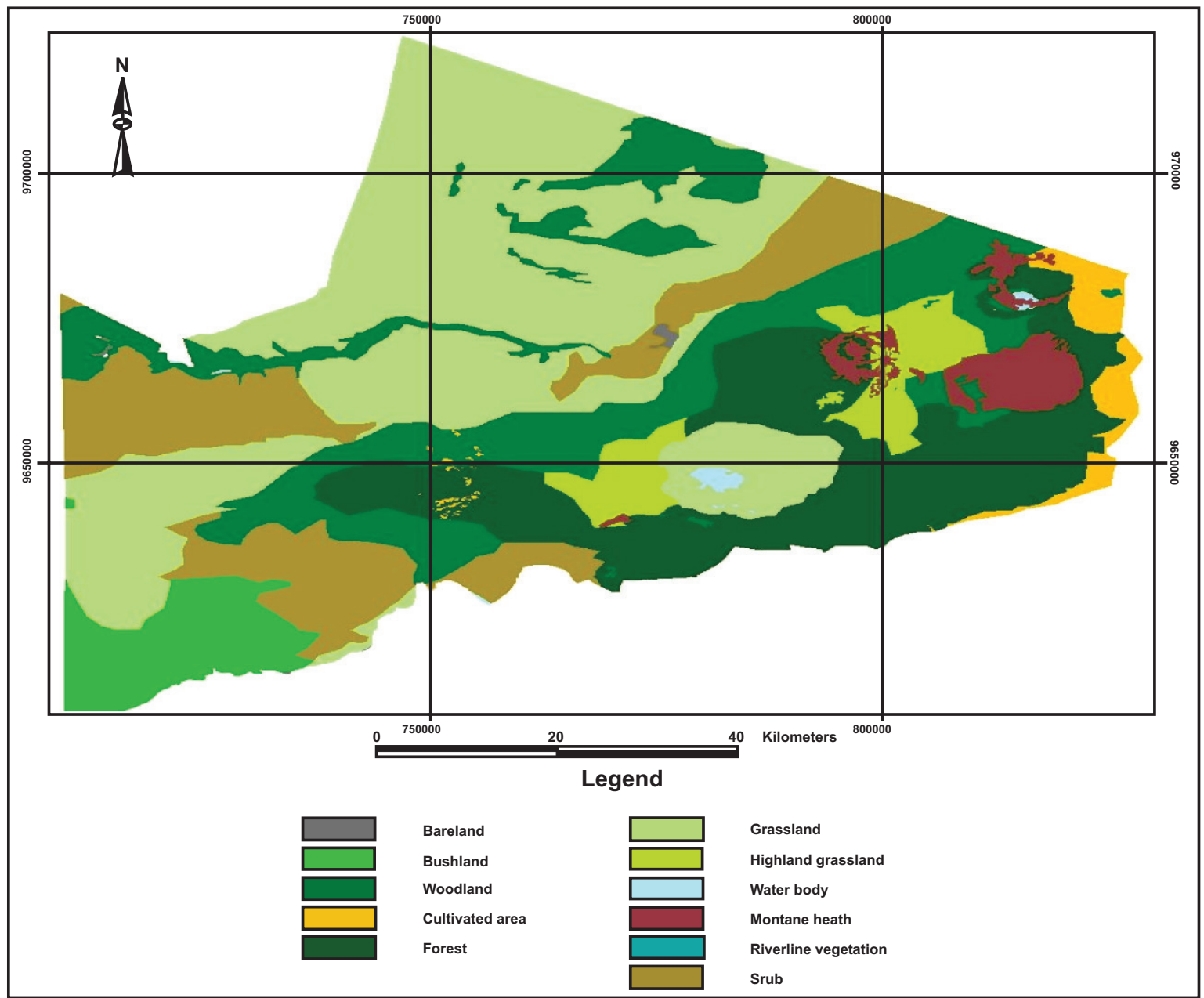

Fig. (5). Map of land cover types of NCA in January 2000.

Table 3. Net Area and Percentage Land Cover Changes for 1975 to 1991 and 1991 to 2000 in Ngorongoro Conservation Area

\begin{tabular}{|c|c|c|c|c|c|c|}
\hline Land Cover Type & $\begin{array}{c}\text { Net Area Change } \\
\text { (Ha) 1975-1991 }\end{array}$ & $\begin{array}{c}\text { \% Cover Change } \\
\mathbf{1 9 7 5 - 1 9 9 1}\end{array}$ & $\begin{array}{c}\text { Net Area Change } \\
\text { (Ha) 1991-2000 }\end{array}$ & $\begin{array}{c}\text { \% Cover Change } \\
\mathbf{1 9 9 1 - 2 0 0 0}\end{array}$ & $\begin{array}{c}\text { Overall Area } \\
\text { Change (Ha) } \\
\mathbf{1 9 7 5 - 2 0 0 0}\end{array}$ & $\begin{array}{c}\text { Overall \% Cover } \\
\mathbf{1 9 7 5 - 2 0 0 0}\end{array}$ \\
\hline \hline Forest & 48812.0 & $52.4 \%$ & -3503.0 & $-3.8 \%$ & 45308.4 & $48.7 \%$ \\
\hline Montane health & 0.0 & 0.0 & 0.0 & 0.0 & 0.0 & 0.0 \\
\hline Woodland & 132351.3 & $11.9 \%$ & -6818.0 & $-6.2 \%$ & 181.651 .5 & 0.0 \\
\hline Scrubland & -48152.8 & -29.13 & 1234.4 & $075 \%$ & 0.0 \\
\hline Bushland & 11973.7 & $42.7 \%$ & 0.0 & 0.0 & 11963.7 & $42.7 \%$ \\
\hline Grassland & 898.1 & $-37.1 \%$ & 330.1 & $0.1 \%$ & -16656.8 & $-37.0 \%$ \\
\hline Highland grassland & 7014.4 & 27.6 & 1733.9 & 6.8 & 8748.3 & $34.4 \%$ \\
\hline Cultivated area & 610.1 & 56.02 & 786.8 & 72.0 & 17587.0 & $16.1 \%$ \\
\hline Bare ground & 775.8 & 2486 & 214.0 & 685.8 & 990.0 & $31.7 \%$ \\
\hline
\end{tabular}

Source: Field Survey data, 2003/2004.

These changes that involved the loss in forest and woodlands were most probably anthropogenically induced due to high livestock grazing pressure, land clearing for cultivation, or forest damages. According to Misana [22, 23] and Perkin [4], forest losses in NCA are due to grass burning by pastoralists, encroachment by farming communities, cutting of tree as building poles, and the harvest of green wood for charcoal burning, as well as damages of forests and woodlands by elephants.

The spatial-temporal vegetation cover changes in NCA suggest a progressive change from grasslands towards 


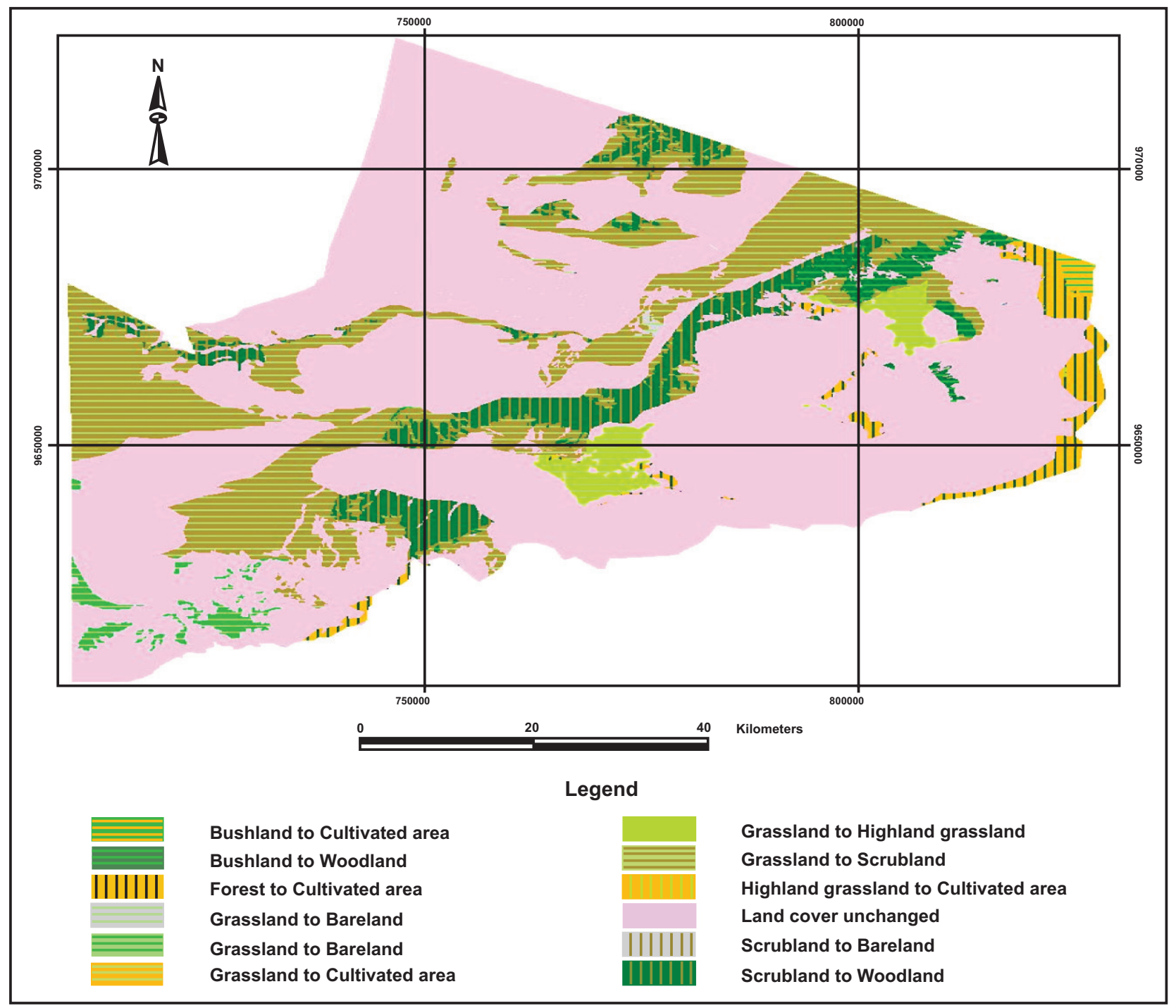

Fig. (6). Map of vegetation cover changes in Ngorongoro Conservation Area between 1975 and 1991.

woody vegetation. This is a common vegetation succession process that has been reported to be taking place in East Africa rangelands and other similar savannah ecosystems [24]. The findings suggest that changes occurring on different vegetation types are multi-directional which may be caused by a wide range of factors. Nonetheless, the changedetection matrix results collaborate the trend in vegetation changes established from net cover change analysis that the net vegetation changes tend to shift from grass dominated cover types towards woodlands. These results are similar to findings by Herlocker [24] who concludes that the ecological succession in the savannah ecosystems tends to move towards a climax of woody vegetation. These processes tend to suppress the herbaceous vegetation, and thus forage yield for grazing cattle. Thus under savannah ecosystems both overgrazing as well as under grazing may result into regeneration of woody vegetation.

Increasing grazing pressure has been identified as one of the main factor driving successional changes in arid rangelands which favour dominance of woody vegetation. According to Archer and Smeins [25], grazing animals affect productivity, composition, and stability of plant assemblages through mediation of plant natality, recruitment, and mortality and may cause directional changes in community structure and function. Sala et al., [26] argues that grazing influences interact with climatic variability and other variables to cause changes in plant communities at various spatial and temporal scales.

Thus, frequent small-scale perturbations associated with grazing contribute to the development of fine-grained mosaics of varying successional states across disturbance has been termed the "intermediate disturbance hypothesis" [27].

Studies by Dougill et al., [28] concluded that rapid intensification of cattle production in semi-arid savannah ecosystem on increasingly formalised block has resulted in vegetation community changes with notably increased dominance of bush species. Similar results were reported 
from elsewhere, for example in Africa [29], Australia [30], India [31], North America [32], and South America [33].

Table 4. Land Cover Change Detection Matrix Map for Ngorongoro Conservation Area between 1975 and 1991

\begin{tabular}{|l|c|c|}
\hline \multicolumn{1}{|c|}{$\begin{array}{c}\text { Land Cover } \\
\text { Type }\end{array}$} & $\begin{array}{c}\text { Area Changes } \\
\text { (Ha) }\end{array}$ & $\begin{array}{c}\text { \%o } \\
\text { Change }\end{array}$ \\
\hline \hline Bush land to Cultivated area & 2556.1 & -0.32 \\
\hline Bush land to Woodland & 11229.0 & +1.4 \\
\hline Forest to Cultivated area & 18715.9 & -2.33 \\
\hline Grassland to Bare land & 467.4 & -0.06 \\
\hline Grassland to Bush land & 7507.9 & +0.93 \\
\hline Grassland to Cultivated area & 15.8 & -0.002 \\
\hline Grassland to Highland grassland & 16502.7 & -2.1 \\
\hline Grassland to Scrub & 151530.9 & +18.87 \\
\hline Highland grassland to Cultivated area & 147.3 & -0.018 \\
\hline Scrub land to Bare land & 297.2 & -0.04 \\
\hline Scrub land to Woodland & 45951.9 & +5.72 \\
\hline Woodland to Scrub land & 692.6 & -0.09 \\
\hline Unchanged land units & 547284.6 & 68.12 \\
\hline Total & & 100 \\
\hline Source: Field Survey data, 2003/2004 & & \\
\hline
\end{tabular}

Source: Field Survey data, 2003/2004.
Table 5. Land Cover Change Detection Matrix Map for NCA $1991-2000$

\begin{tabular}{|l|r|r|}
\hline \multicolumn{1}{|c|}{ Land Cover Type } & Area Changes (Ha) & \% Change \\
\hline \hline Cultivated area to Forest & 713.2 & +0.09 \\
\hline Forest to Cultivated area & 1170.2 & -0.15 \\
\hline Forest to Highland grassland & 1830.9 & -0.23 \\
\hline Forest to Woodland & 355.2 & -0.04 \\
\hline Highland grassland to Woodland & 99.8 & +0.01 \\
\hline Woodland to Bare land & 214.1 & -0.02 \\
\hline Woodland to Cultivated area & 329.7 & -0.04 \\
\hline Woodland to Grassland & 330.1 & -0.04 \\
\hline Woodland to Scrub & 487.4 & -0.08 \\
\hline Unchanged land units & 797367.4 & 99.3 \\
\hline Total & $\mathbf{8 0 2 8 9 8 . 0}$ & $\mathbf{1 0 0 . 0}$ \\
\hline Source: Field Survey data, 2003/2004 & &
\end{tabular}

Source: Field Survey data, 2003/2004.

Gilson [34] reported cyclic changes in tree abundance in Serengeti ecosystem within $100-500$ years. Whereby, the short term changes in tree/grass abundance were attributed to localise disturbances rather that climatic shifts. The evidence from Serengeti ecosystem and the results from this study suggest that policy change in NCA, which restricted livestock to limited areas, has created a local disturbance that

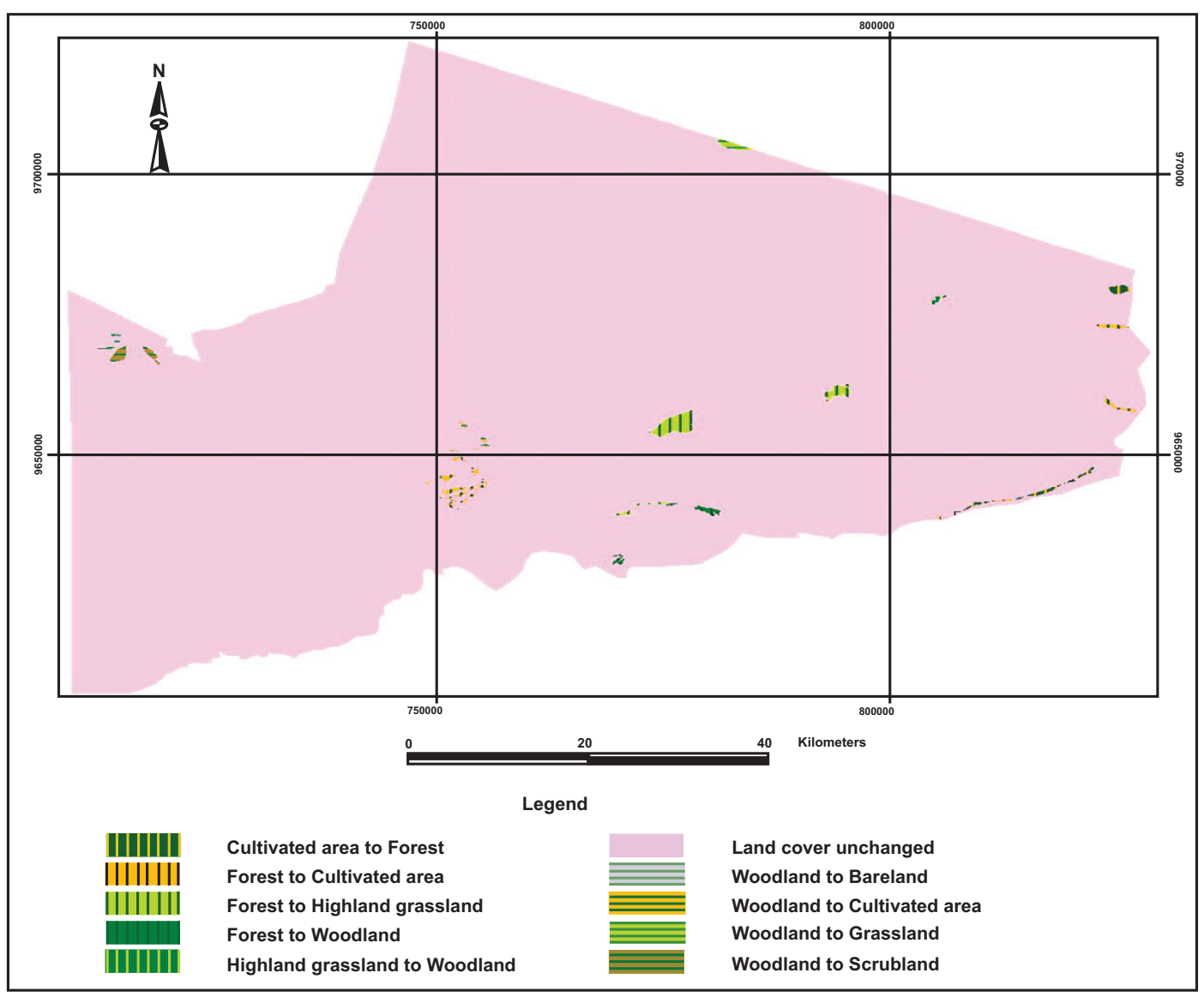

Fig. (7). Map of vegetation cover changes NCA between 1991 and 2000. 
brought about vegetation changes favouring dominance of woody species.

\section{CONCLUSION AND RECOMMNEDATIONS}

\subsection{Conclusion}

The study gives a general indication that the ecosystem in Ngorongoro area is undergoing changes, which favours dominance of woody species at the expense of grass species. This changes implies a threat to the wellbeing of grazers both domesticated and wild game which are dependent on grass for grazing. As a result the livelihoods of pastoralists who are dependent on livestock herd productivity are being threatened. In turn the pastoralists are resorting to cultivation, which in the long run may be detrimental to sustainability of both the pastoralists and the ecosystem in general.

Furthermore, the results suggest that extensive pastoral land use is an important component for maintaining savannah ecosystems of East Africa, and that disruption of traditional pastoral systems may lead to ecological changes detrimental to both wildlife conservation as well as pastoral livelihoods.

\subsection{Recommendations}

Pastoralists have traditionally utilized arid and semiarid rangelands under communal property regime and practised transhumance movements, based on seasonality of resource abundance. The conservation policies adopted in the NCA has disrupted the traditional pastoral land use system that has maintained the parkland landscapes, that supports tourism industry. Thus, pastoralism generates the ecological disturbances that have sustained the savannah ecosystem in NCA. It is recommended that restrictive conservation policies that limit pastoral mobility and emphasize on sedentarisation are detrimental to pastoral production and wildlife conservation, therefore future pastoral development policies should provide for controlled livestock mobility.

High grazing pressure in the study areas has induced retrogressive ecological changes, which reduces primary productivity of rangelands. It is recommended that the grazing systems should be premised on "non-equilibrium model" for grazers in arid environment, which allow flexibility and livestock mobility.

\section{REFERENCES}

[1] Ministry of Natural Resources and Tourism, (MNRT). Results of Preliminary Survey of Selected Villages in NCA: SUA-NCAA Research Programme. Dar es Salaam: NORAD/Government Printer, 1998.

[2] Boone RB, Lackett JL, Galvin KA, Ojima DS, Comptonn JT. Links and Broken Chains: evidence of human-caused changes in land cover in remotely sensed images, environmental science \& policy. 2007; 10. Available from: http://www.elsevier.com/locate/envsci [Cited: 6 October 2007].

[3] Perkin SL. Integrating Conservation and development: an evaluation of multiple land-use in the Ngorongoro conservation area, Tanzania. Unpublished PhD Thesis. University of East Anglia, UK 1993.

[4] Perkin SL. Multiple Land-use in the Serengeti Region. The Ngorongoro Conservation Area. In: Sinclair ARE, Arcese P, Eds. Serengeti II: dynamics, management and conservation of an ecosystem. Illinois: University of Chicago Press 1995; pp. 571-87.

[5] Campbell K, Borner M. Population trends and distribution of Serengeti Herbivores: implication for management. In: Sinclair
ARE, Arcese P, Eds. Serengeti II: dynamics, management and conservation of an ecosystem. Illinois: University Chicago Press 1995; pp. 117-45.

Homewood KM, Rodgers WA. Maasailand ecology: pastoral development and wildlife conservation in Ngorongoro, Tanzania. Cambridge: University of Cambridge Press 1991.

[7] United Republic of Tanzania, (URT). 2002 Population and Housing Census General Report. Dar es Salaam, Tanzania Government Printers 2003.

[8] WCMC. Interactive map showing endangered habitats, birds and animals, UNEP-world conservation monitoring centre UK 1997. Available from: http://www.unep.wcmc.org/imaps/gb2002/book/ viewer.htm [cited: $15^{\text {th }}$ June 2002].

[9] International Union for Conservation of Nature, (IUCN) Ngorongoro Conservation and Development Project, Final Report: Phase I. Nairobi: IUCN 1990.

[10] Galvin KA. Nutritional ecology of pastoralists in dry tropical Africa. Am J Biol 1992; (4): 209-56.

[11] Galvin KA, Boone RB, Smith NM, Lynn SJ. Impact of climate variability on East African Pastoralists: linking social science to remote sensing. Clim Res 2001; 19: 161-72.

[12] Runyoro VA. 2006-2016 Ngorongoro Conservation Area, Second General Management Plan. Unpublished Draft Report, Ngorongoro 2006.

[13] McCabe JT, Schofield EC, Pederson GN, Lekule A, Tumaini A. Food security and nutrition among the Maasai of the Ngorongoro conservation area, Ngorongoro conservation and development project technical report no. 10. Nairobi IUCN 1989.

[14] Kauth RJ, Thomas GS. The Tasselled Cap: a graphic description of the spectral-temporal development of agricultural crops as seen by LANDSAT. Conference Proceedings. Indiana: Purdue University of West Lafayette 1976; pp.4B-41 to 4B-51.

[15] Lillesand TM, Kiefer RW. Remote sensing and image interpretation. $2^{\text {nd }}$ ed. Chicago: John Wiley and Sons Inc. USA 1987.

[16] Hall PAV. Decision support systems for sustainable development: experience and potential- international conference on decision support systems for sustainable development: software technology for agenda 21, organized by United Nations University, Ontario: International Institute for Software Technology and IDRC. June 25-29, 1997.

[17] ERDAS, 2007. ERDAS IMAGINE, Leica geosystems geospatial imagining. Erdas Labs, Texas, US. Available from http://www.gileica-geosystems.com/LGISubIx33x0.asp [cited: $25^{\text {th }}$ June 2009].

[18] Herlocker D, Dirshl HJ. Vegetation of Ngorongoro conservation area, Tanzania Canadian wildlife service report series no. 19. Ottawa: Canada. Ottawa Printing Office 1972.

[19] Pratt DJ, Gwynne MD. Rangeland management and ecology in East Africa. London: Hodder and Stoughton 1977.

[20] Lissu T. Pastoral Lands: the case study of the Ngorongoro conservation area, law, social justice and global development (LGD) 1: Warwick, UK. Available from: http://elj.warwick.ac.uk/ global/issue/2000-1/lissu.html [cited: $3^{\text {rd }}$ March 2007].

[21] Makacha S, Frame GW. Population trends and ecology of Maasai pastoralists and livestock in Ngorongoro conservation area, Serengeti Wildlife Research Institute, Contribution No. 338. Serengeti: Arusha Mimeograph 1986.

[22] Misana SB. An assessment of vegetation change in Ngorongoro conservation area. Ngorongoro conservation and development project. technical report no. 10. Nairobi, Kenya: IUCN Regional Office for East Africa 1989.

[23] Misana SB. Vegetation change. In: Thompson ME, Eds. Multiple Land Use: the experience of Ngorongoro conservation area, Tanzania. Gland Switzerland and Cambridge: IUCN 1997; pp. 97110.

[24] Herlocker D. Rangeland resources in East Africa: their ecology and development. Nairobi: GTZ 1999.

[25] Archer A, Smeins FE. Ecosystem level process. In: Heistschmidt J, Stuth JW, Eds. Grazing Management: an ecological perspective chp. 5. Available from: http://www.cnrit.tamu.edu/rlem/text book Chapter 5. html [cited: $3^{\text {rd }}$ December 2007].

[26] Sala OE, Parton WJ, Joyce LA, Lauenroth WK. Primary production of the central grassland regions of the United States. Ecology 1988; 69: 40-5.

[27] Connell JH. Diversity in tropical rain forests and coral reefs. Science 1978; 1302-10. 
[28] Dougill AJ, Heathwaite AL, Thomas DSG. Vegetation change and system resilience: soil water movement and nutrient cycling in semi-arid rangeland. InterScience 1988; 12 (3): 443-59.

[29] Van Vegten JA. Thornbush invasion in a savannah ecosystem in Eastern Botswana. Vegetatio 1983; (56): 3-7.

[30] Harrington GN, Wilson AD, Young MD. Management of Australia's Rangelands. Melbourne: CSIRO 1984.

[31] Singh JS, Joshi MC. Ecology of the semi-arid regions of India with emphasis on land-use. In: Walker BH, Ed. Management of semiarid ecosystems. New York: Elsevier 1979; pp. 243-73.
[32] Smeins FE. Origin of the Brush problem- a geographical and ecological perspective of contemporary distributions. Conference Proceedings. Lubbock, US 1984; pp. 5-16.

[33] Schofield CJ, Bucher EH. Industrial contributions to desertification in South America. Tree 1986; (1): 78-80.

[34] Gilson T. Testing non-equilibrium theories in Savannah: vegetation change in Tsavo national park, Kenya. Ecol Complex 2004; 1(4): 281-98.

(C) Elliott P. Niboye; Licensee Bentham Open.

This is an open access article licensed under the terms of the Creative Commons Attribution Non-Commercial License (http://creativecommons.org/licenses/by$\mathrm{nc} / 3.0 /$ ) which permits unrestricted, non-commercial use, distribution and reproduction in any medium, provided the work is properly cited. 